\title{
Do Foreign Direct Investment Inflows Impinge Gross Domestic Product? A Venture Out for Asean
}

\author{
Nida Rahman ${ }^{1}$, Mohd. Nayyer Rahman ${ }^{2}$ \\ ${ }^{1}$ Department of Economics, Aligarh Muslim University, India. \\ ${ }^{2}$ Department of Commerce, Aligarh Muslim University, India. \\ Email: nidarahman88@gmail.com,nayyer49@gmail.com
}

Received: December 4, 2017; Accepted: January 9, 2018; Published: February 2, 2018

Permalink/DOI: http://dx.doi.org/10.17977/um002v10i12018p064

\begin{abstract}
Foreign Direct Investment, since decades, has taken over other sources of debt flows both in developed as well as emerging economies of the world. The globalisation phenomenon that gauges back to the late 80 s and early 90 s saw in the opening up of economies a plethora of opportunities to integrate economies across the globe. One major instance of the speeding globalisation was seen in the form of bilateral and multilateral agreements among nations to enhance cooperation on mutual fronts. ASEAN, one such conglomeration, saw its inception back in 1967 and with the steering of global identity, the participating members extended from five founding members to other countries of Southeast Asia as well. The ameliorating figure of Foreign Direct Investment Inflows in the ASEAN region has stirred a need for quantifying the overall effect of FDI Inflows on Gross Domestic Product of the region. The present research note intends to capture this impingement of Foreign Direct Investment Inflows on Gross Domestic Product of the Ten Southeast Asian member nations which together constitute ASEAN. The data is fetched from UNCTAD Statistics database for a time range of 1980-2015. Panel regression technique is deployed to meet ends. The results of Random Effects Panel Regression indicate a significant and positive impingement of Foreign Direct Investment Inflows on Gross Domestic Product of ASEAN member states. The outcome thus throws light on how Foreign Direct investment Inflows has contributed to the Gross Domestic product of ASEAN and further exploration in the area will blossom the relationship.
\end{abstract}

Keywords: Foreign Direct Investment Inflows, ASEAN, UNCTAD. JEL Classification: F10, F21

\section{INTRODUCTION}

The Globalisation of economies saw in its spectrum a rise and expansion in groups formed of nations with varied histories and geo-political features. This congery of economies, in plain terms, regional groups has garnered galore of notice from researchers from their very inception, but it was in 90s that created a much upheaval into the matter eventually fuelling the inquisitiveness of academicians and policy makers. The Asian dimension of globe that homes a proportion of 59.69 percent of the total population of the entire globe acknowledges an expansed congery of Ten Southeast Asian nations i.e. the ASEAN (Association of Southeast Asian Nations) that make up 3 percent of the world's population. The regional bloc has witnessed a lot of development since its 
formation in August 8, 1967. Initially, five Southeast Asian countries which registered as the founding members of ASEAN were Indonesia, Malaysia, Singapore, Phillipines, and Thailand. With time, ASEAN met a stack of hurdles debilitating its major economic cooperation objectives and suppressing the potential benefits that could have arisen from the origin. All this is apparent from the condition the bloc recorded in the cold war era when there emerged enormous chaos among the member countries in respect of Vietnamese war on Cambodia and China's strong influence over powers of other member states. In addition, the Asian crisis of 97-99 aggravated the disheartening stand of ASEAN on the world platform. With the crisis blowing away the economy of Thailand, ASEAN soon stumbled as other member economies followed in the downsurge. Despite all this, with the realisation of the main purpose of ASEAN's enactment, the member countries came together to resolve over disputes and reframe its propaganda to take hold of its economic stand in the world order. Among the measures taken by ASEAN to reconstitute its economic image after the Asian crisis washed off its shores, a prominent one was its commitment towards the ASEAN Free Trade Agreement (AFTA) (Narine, 2008). ASEAN, thus post the cold war era expanded its fora from being a group of five to a group of ten by adding other states of Southeast Asia as its new members (Brunei Darussalam, Laos PDR, Vietnam, Cambodia and Myanmar), albeit in different phases (Brunei Darussalam in 1984, Laos PDR and Myanmar in 1997, Vietnam in 1995, and Cambodia in 1999).

The FDI activity in the ASEAN region was hit hard by the Asian crisis in the 1997-99 period, though it tried to resume its toll reached in the middle of 90s. However, individual member states made a different picture of FDI activity which contradicts that of the total FDI attracted by ASEAN as a whole. Among the members of ASEAN, Singapore fetched the greatest amount of Foreign Direct Investment Inflows even in the crisis period. However, Indonesia for the most of the time frame gathered a negative figure on the Foreign Direct Investment Inflows chart. For others, the phenomenon was a mixture of both up and down turns but for ASEAN as one economic entity, the FDI figures witnessed a severe dip during the crisis years and even after crisis resumed in bits and coins. However, a multitude of developments in the regional groups policy towards trade and investment has accentuated its position to an overwhelming position of third in the top three trading blocs of the world; EU and NAFTA being the first and second. A major development that registers in the listicle lately is the inception of AEC (ASEAN Economic Community) in 2015. The community further fosters trade and investment opportunities in the region by offering a wide single common market for goods, services, investment, skilled labour and freer flow of capital between all member countries (ASEAN, 2017). On 40th Anniversary of ASEAN, the Vision 2020 was revised to form ASEAN Community with an objective of creating an economic and political community (Iqbal \& Rahman, 2015). Pushed ahead on the world platforms by these initiatives and others like binding trade agreements with countries outside of ASEAN (AFTA, AIFTA, ASEAN-China FTA, AANZFTA, APT, ASEAN PLUS 6, RCEP etc.) the Southeast Asian region is prognosticated to grow by $4.8 \%$ in 2017.

The interesting pattern of FDI Inflows into the ASEAN region instigates studying its impacts on Gross Domestic Product of the conglomeration. The reason that lies beneath the growth in the idea of countries, both developing and 
developed to cater more from foreign capital is its apparent benefit of not adding up to debt and its user-friendliness of being non-volatile in nature as against debtcreating flows. This advancement in acknowledging FDI as a positive force has laid its hand in the development and pulling out of a majority of countries from financial instability and crisis. Since the early 1980s, most developing countries have significantly eased restrictions on foreign investment, believing that FDI promotes growth- but does it really? (Herzer, 2012). As is evident from the databases, FDI Inflow has shown a rising trend in the ASEAN region in the last decade with infrequent dips in quantity. The graphical presentation of all ASEAN countries FDI figures since 1980 is shown through a panel of graphs in Figure 1. Among all the members, Singapore fished highest inflows given its financial soundness and already accomplished economic development. However, in the 2010-2015 period, FDI Inflows to CLMV countries that lagged behind since decades has stirred to a high of 14 percent in 2015 as against 10 percent registered in 2014 (ASEAN, 2016). Total FDI Inflows to the ASEAN region dipped in the last fiscal on account of wide disparities in individual FDI seeking. Though the FDI pouring has been a mixed pattern for ASEAN on the whole, the forging ahead of the ASEAN Economic Community is prognosticated to pull foreign investors to the congregation as the AEC is fuelled with all the positives of investor confidence.

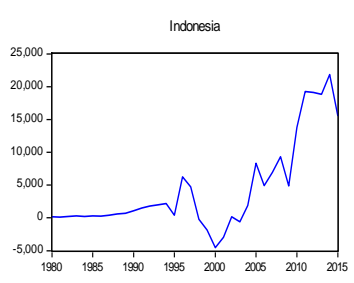

FDII

Thaland

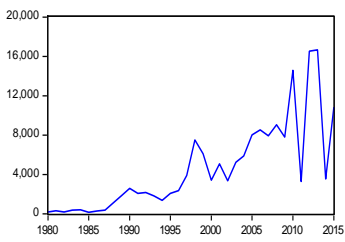

LaO PDR

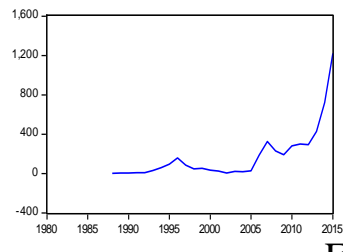

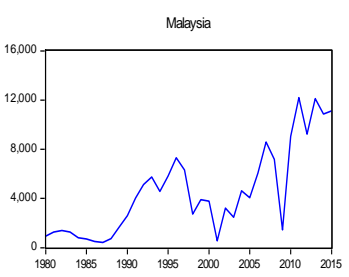
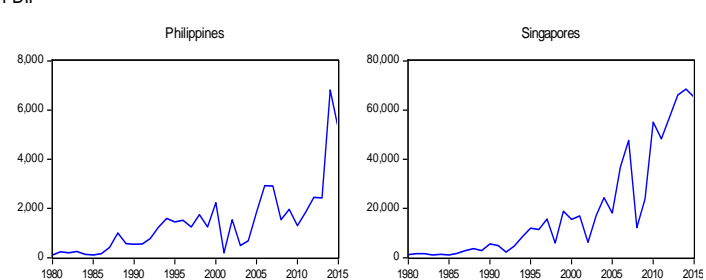

Vietnan

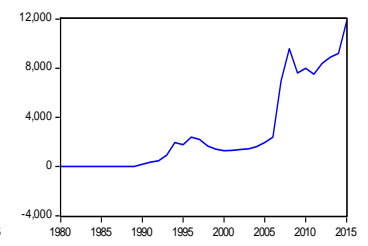

Brunei

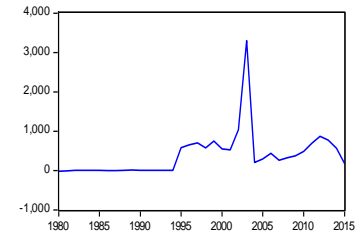

Figure 1. FDI Inflows in ASEAN member states Source: Prepared by author through E-views 9

This amelioration in FDI is whether a catalyst for economic growth of ASEAN or a debilitating factor is the crux of the present research note. Academic history has in its record a great deal of studies gauging the impact of FDI on GDP of individual economies, be it developing or emerging or developed. However, not much is explored regarding the particular impingement of FDI Inflows on GDP of ASEAN-10 congery. The present study is an addition to the existing ones save it offers substance to those delving into ASEAN. 


\section{LITERATURE REVIEW}

A gob of research exists in the academic atmosphere of foreign investment that caters to the objective of carving out the effects of the revered phenomenon on economic growth and multiple macroeconomic indices. Theories of Foreign Direct Investment lay the determinants that pull FDI into recipient countries and also reflect on its growth related impacts. Neo-classical growth theory and the endogenous growth theory have lent substantial evidence to Foreign Direct Investment prompted growth, albeit in varying forms. De Mello (1997) in his paper analyses the literature on the particular effect of Foreign Direct investment on economic growth of developing economies. His insights of the neo-classical and endogenous growth theory bring into light the contribution of both theories to explanation of FDI led growth; the former being elaborating on the short run impacts only whereas the latter detailing over the long run after effects of FDI on economic growth. The endogenous growth theory explains the long run effect of FDI on growth by affecting the production pattern of the recipient country through a chain of positive externalities and technology spillovers scattering from FDI in the recipient economy production channel and thereby resulting into increasing returns in production (De Mello, 1997; Borenztein, De Gregorio, \& Lee, 1998; Olofsdotter, 1998; Berthelemy \& Demurger, 2000; Li \& Liu, 2005; Ford et al., 2008). However, Mello (1997) study fetches peculiar result of growth led FDI through his proposition of host country's determinants of FDI having a robust linkage with FDI Inflows; much stronger than FDI with growth. Further, the spillovers spewed by FDI in the recipient country such as technological strides, knowledge movement, skill transfers, know-how transfers etc. holds paramount significance in determining the growth effect of FDI on host country. De Mello (1999) explores the effect of FDI on growth of OECD and non-OECD countries over a time frame of 1979-90 utilizing both times series and panel data. In what emerges out in his exploration of the subject is that FDI impact growth of recipient countries in proportion of what it does to domestic investment. Whether or not the growth is led by FDI depends on the power of substitutability and complementarity of FDI with domestic investment. The results of a multitude of studies delving into the issue indicate that Foreign Direct Investment promotes the economic growth of recipient countries, albeit in environments favoured by policy decisions, trade and investment regimes, political stability, corruption level, Education level, Infrastructure expenditure, financial openness and institutional framework. Also, a lot of growth effect of FDI depends on the actual growth of the recipient country. The per capita income, absorptive capacity, industry soundness etc. all contribute in attracting FDI and thus enriching the economy with FDI.

A great number of works have taken into account the proposition of country specific characteristics having an impression over growth effects of Foreign Direct Investment. Most of them are driven by the hypothesis of FDI led growth by way of technology diffusion. Bhagwati (1978) lent extensively to FDI growth study by excavating how trade regimes of recipient nations add to the growth effects of FDI. The study states that export promoting countries grow with the incoming of FDI whereas it is converse in the case of import-substituting countries. The similar notion was forged ahead by studies of Balasubramanyam, Salisu \& Sapsford (1996); Brecher \& Alejandro (1977); Kohpaiboon (2003); Alici 
\& Ucal (2003); Hsiao \& Hsiao (2006). Further researches have taken into consideration related factors like institutional capability, financial robustness, labour productivity etc. that once impacted considerably by inward FDI affects growth of receiving countries. Olofsdotter (1998) concluded FDI to be positively marking the economic growth of a sample of 50 countries. This positive result depends largely on the institutional power of the host country; larger it is, the more affirmative effect of FDI it poses on growth rate of host nation. In similar context taking into purview the varying features of host nations into gauging the impact of FDI on their growth, Hermes \& Lensink (2003) admit the relevance of host country's financial sector in determining the growth benefits of FDI. For a strata of 67 countries of Asia, Latin America and Sub-Saharan Africa, the study reveals the benign effect of FDI for countries in the datapool showcasing a developed and sound financial arrangement. Only 37 countries of Latin America and Asia out of the total dataset give evidence to positive effect of FDI on economic growth; fulfilled by their well developed financial arrangements. However, the rest economies of Sub-Saharan Africa proved wary of any positive growth effect of FDI because of their rot arrangement of financial sector. $\mathrm{Vu}$ (2008) studies the influence of FDI on economic growth through a way into enhancing the productivity of domestic labour. Though the study explores the case of Vietnam only, the results are equally relevant as the cross country studies reflect. The results indicate that FDI in Vietnam influence labour productivity in the affirmative and also positively affects economic growth, however with distinct impacts across sectors.

The debate over Foreign Direct Investment affecting economic growth in the favour or against has witnessed gross variations. The explorations have showcased wide asymmetry in both results and approaches acted upon by researchers. The results are perceived different for individual economies and differently for group of economies. Similarly, across a particular group of countries also, it is not a surprise that the results are widely sparsed led by idiosyncratic behaviours of host economies. In particular relation to ASEAN region and economies falling in East Asia or Southeast Asia, many research works have provided enough support to the idea of Foreign Direct Investment impinging Gross domestic product either directly or indirectly. In this line, studies conducted by Baharumshah \& Thanoon (2006); Kotrajaras, Tubtimtong \& Wiboonchutikula (2011); Zhang (2001) reflect the importance of country-specific characteristics in determining whether inward Foreign Direct Investment is growth ameliorating or growth subjugating. These three studies take into analysis selected East Asian countries and some countries of Latin America. Baharumshah \& Thanoon (2006) analyses the FDI growth hypothesis for a cluster of eight Asian countries (China, South Korea, Fiji, ASEAN-5) and the outcome is indicative that FDI cause growth in the short and long run alike for the panel of eight Asian countries. Kotrajaras, Tubtimtong \& Wiboonchtikula (2011) analyses the same idea with a slight reorganization of the dataset into subgroups of countries of East Asian region with a particular level of development. For the fifteen Asian countries, the panel data estimation technique suggest that FDI has an influence over growth but largely based on the income bar the particular country falls into. For high-income countries, the effect is extensive and positive; for low-income economies, the association is limited with almost a negligible opportunity from FDI. The 
importance of country unique characteristics has time and again being repeated in the majority of literature on FDI growth debate. Zhang (2001) also concludes on the same platform. His findings reveal that FDI tends to sway growth positively for economies having a favourable trade regime, human resource development, export led FDI and sound overall economic system. Driven by this general finding, his study concludes that FDI agglomerates growth in Hong Kong, Indonesia, Singapore, Taiwan, and Mexico as against countries of Latin America as East Asia is more empowered in terms of country unique capabilities in absorbing the benefits emerging from incoming of FDI.

Causal connections running from FDI to Economic Growth or from Economic Growth to FDI or both are also discussed widely in recent empirical works. In specific cases of empirical researchers on ASEAN, studies by Merican (2009); Pradhan (2009); Moudatsou \& Kyrkilis (2011) delve on the causality linkage between FDI and Economic Growth. Pradhan (2009) find out a bidirectional causality between FDI and Economic Growth for the entire panel of ASEAN-5 countries, albeit the causality only emerges for Singapore and Thailand at individual country level. Moudatsou \& Kyrkilis (2011) also conclude the causality to be two-directional specifically for Indonesia and Thailand among the 5 ASEAN countries; no causality among other countries. Merican (2009) arrives on the final word that FDI is much more growth enhancing for selective ASEAN countries than domestic investment (Malaysia and Indonesia).

The extensive literature review in the area unleashes the spectrum of approaches and ideas undertaken to explore the issue. The present study like many other studies in the area utilizes panel data econometric method to meet ends. The present study takes into excavation all the ten members nations of ASEAN for studying the impact of FDI Inflows on GDP which is a strong departure from past studies on the topic that have inclined more so with the five prominent member nations of ASEAN or the four ASEAN members. Also, the present research note offers a unique sample period of 1980-2015; which forms a huge and long-term dataset for devising policy measures on the economic association.

\section{METHOD}

The prime objective of the present research piece is to find the exact impingement Foreign Direct Investment Inflows poses on the Gross Domestic Product of ten ASEAN member states. For the purpose, panel data for the ASEAN economies is fetched from UNCTAD STAT database and Random Effects model of Panel Regression is acted upon the data to reach ends. The Foreign Direct Investment Inflows and GDP figures are in US\$ Million. The GDP figures for all economies are at current and constant prices with the base year 2005. However, the data for FDI Inflows for some economies of ASEAN like Cambodia, Laos PDR, Vietnam and Myanmar is missing for some years as these economies registered in the congery in later years on varied reasons of political fragility, wars, and closed economy. Thus, the dataset is on the whole an unbalanced panel dataset.

The Random Effects Model of Panel Regression is utilized when indicated suitable by the Hausmann test. A simple formulation of Random Effects model is:

$$
\mathrm{Y}_{\mathrm{it}}=\beta \mathrm{X}_{\mathrm{it}}+\alpha+\mathrm{u}_{\mathrm{it}}+\varepsilon_{\mathrm{it}}
$$


We, in our analysis, run the Random Effects model first as it is accommodated with an advantage of assuming that an individual entities error term is uncorrelated with the regressor which qualifies the time invariant variables to be treated as predictors. However, engrossed with some bias, it is tedious to choose among fixed or random effects model at random. Thus, the Hausmann test declares the model fit for the analysis. The Hausmann test testifies whether the unique errors are correlated with the regressors or not. The null hypothesis of Random Effect Model is appropriate is rejected or accepted. The alternative hypothesis is Fixed Effect Model is appropriate (Green, 2008).

\section{RESULT AND DISCUSSION}

The Random Effects Model is run to gauge the impact of FDI Inflows on GDP for ten ASEAN member countries. The results of the model are displayed in Table 1.

Table 1. Random Effects Panel Regression Results

\begin{tabular}{ccccc}
\hline \multicolumn{5}{c}{ Dependent Variable: GDP } \\
\hline \multicolumn{5}{c}{ Method: Panel EGLS (Cross-section random effects) } \\
\hline Variable & Coefficient & Std. Error & t-Statistic & Prob. \\
\hline C & 57825.48 & 31990.61 & 1.807576 & 0.0716 \\
\hline FDII & 8.522280 & 0.658791 & 12.93624 & 0.0000 \\
\hline \multicolumn{5}{c}{ Effects Specification } \\
\hline \multicolumn{5}{c}{ S.D. } \\
\hline Cross-section random \\
\hline \multicolumn{5}{c}{ Idiosyncratic random } \\
\hline \multicolumn{5}{c}{ Weighted Statistics } \\
\hline R-squared & 0.333143 & Mean dependent var & 14756.80 \\
\hline Adjusted R-squared & 0.331158 & S.D. dependent var & 112915.4 \\
\hline S.E. of regression & 92388.08 & Sum squared resid & $2.87 \mathrm{E}+12$ \\
\hline F-statistic & 167.8561 & Durbin-Watson stat & 0.144713 \\
\hline Prob(F-statistic) & 0.000000 & \\
\hline Sout
\end{tabular}

Source: Prepared by author through E-views results

The Random Effects model is fit as is indicated by the probability value of F-statistic. Further, from Table 1, it is clear that Foreign Direct Investment Inflows has an impact over GDP of the Ten ASEAN member countries in the affirmative and in substantial degrees. Foreign Direct Investment Inflows as the independent or explanatory variable is able to explain 33 percent variation in the GDP of ASEAN member states as a panel. The individual country results may vary given difference in policies and arrangements.

In furtherance to the econometric technique to panel regression, it is a must to check whether the selection of Random Effects Model is suitable or Fixed Effects Model will fulfill well for the panel dataset. Thus, the Hausmann Test is acted upon the panel to verify the viability of Random Effects or Fixed Effects model. The outcome of Hausmann Test is provided in Table 2. 
Table 2. Hausmann Test Results

Correlated Random Effects - Hausman Test

Equation: Untitled

Test cross-section random effects

\begin{tabular}{lrrr}
\hline Test Summary & Chi-Sq. Statistic & Chi-Sq. d.f. & Prob. \\
\hline Cross-section random & 0.246560 & 1 & 0.6195 \\
\hline
\end{tabular}

Source: Prepared by author through E-views results

Null: Random Effect Model is appropriate

Alternative: Fixed Effect Model is appropriate

As is evident from Table 2, the Probability value corresponding to Crosssection random is greater than 0.05 or furthers the $5 \%$ level of significance, it is fit to say that the selection of Random Effects model is suitable for the present panel dataset of ASEAN. If, in any case, probability value would have been something smaller than 0.05, Fixed Effects model of estimation would have served the purpose of estimation.

\section{CONCLUSION}

ASEAN has surpassed a majority of leading economies in garnering FDI Inflows since last two decades. Also, in comparison with other regional groups, it has, with its export and FDI led growth strategy acquired great amounts of foreign capital. Being an amalgamation of countries with varying economic development, economic size, institutional set up etc., the aftereffect of FDI on GDP is bound to vary when taken in lone context. However, the present research takes the congery for the ascertainment of FDI Inflows impingement on its GDP as one economic entity. As delivered by analytical outcome, FDI Inflows do impinge GDP of ASEAN in the positive direction thus manifesting the majority view of FDI encouraging GDP. The major conclusion that draws from the analysis is that ASEAN member nations must follow up a policy of greater FDI inflow in order to achieve greater economic growth. In addition to the empirical results, the theoretical study of the phenomenon in ASEAN region open up that FDI Inflows can cater to the GDP growth of ASEAN countries with much greater pace provided all countries are able to fetch FDI in a balanced proportion rather than some countries like Singapore and Thailand remaining the prominent in luring greater FDI's. Albeit, overall impact of FDI on GDP is sound and promising for GDP of ASEAN. Greater FDI lead to greater GDP.

\section{REFERENCES}

Alici, A. A., \& Ucal, M. S. (2003). Foreign Direct Investment, Exports and Output Growth of Turkey: Causality Analysis. Paper presented at European Trade Study Group (ETSG) Fifth Annual Conference: Madrid.

ASEAN. (2017). Investing in ASEAN. Retrieved from: http://asean.org/storage/ 2017/01/Investing-in-ASEAN-2017-.pdf.

ASEAN. (2016). ASEAN Investment Report 2016: Foreign Direct Investment and MSME Linkages. Retrieved from http://asean.org/storage/2016/09/ Shared _James-Zhan_ASEAN-Investment-Report-2016-29-8-2016.pdf. 
Balasubramanyam, V. N., Salisu, M., \& Sapsford, D. (1996). Foreign Direct Investment and Growth in EP and IS countries. The Economic Journal, 106(434), 92-105.

Baharumshah, A. Z., \& Thanoon, M. A. M. (2006). Foreign Capital Flows and Economic Growth in East Asian countries. China Economic Review. 17, 70-83. doi:10.1016/j.chieco.2005.09.001.

Berthelemy, J. C., \& Demurger, S. (2000). Foreign Direct Investment and Economic Growth: Theory and Application to China. Review of Development Economics, 4(2), 140-155. doi: 10.1111/1467-9361.00083.

Bhagwati, J. N. (1978). Anatomy of Exchange Control Regimes. In Anatomy and Consequences of Exchange Control Regimes (pp. 7-52). NBER.

Borenztein, E., De Gregorio, J., \& Lee, J. W. (1998). How does Foreign Direct Investment affect Economic Growth? Journal of International Economics. $45,115-135$.

Brecher, R. A., \& Diaz-Alejandro, C. F. (1977). Tariffs, Foreign Capital and immiserizing growth. Journal of International Economics. 7, 317-322.

De Mello, L. R. (1997). Foreign Direct Investment in Developing Countries and Growth: A Selective Survey. Journal of Development Studies, 34(1), 1-34. doi: 10.1080/00220389708422501.

De Mello, L. R. (1999). Foreign Direct Investment-led Growth: Evidence from Time Series and Panel Data. Oxford Economic Papers, 51, 133-151.

Ford, T. C., Jonathan, C. R., \& Bruce, T. E. (2008). Foreign Direct Investment, Economic Growth, and the Human Capital Threshold: Evidence from US States. Review of International Economics, 16, 96-113.

Green, W. H. (2008). $6^{\text {th }}$ Ed. Econometric Analysis. NJ: Prentice Hall.

Hermes, N., \& Lensink, R. (2003). Foreign direct investment, financial development, and economic growth. The Journal of Development Studies, 40(1), 142-163. doi: 10.1080/00220380412331293707.

Herzer, D. (2012). How Does Foreign Direct Investment Really Affect Developing Countries' Growth? Review of International Economics, 20(2), pp. 396-414.doi: 10.1111/j.1467-9396.2012.01029.x

Hsiao, F. S. T., \& Hsiao, M. W. (2006). FDI, Exports, and GDP in East and Southeast Asia- Panel Data Versus Time Series Causality Analyses. Journal of Asian Economics, 17, 1082-1106. doi:10.1016/j.asieco.2006.09.011.

Iqbal, B. A., \& Rahman, M. N. (2015). Contribution of ASEAN-6 SMEs to Economic Growth of ASEAN. Economics World, 3(11-12), 258-269. doi: $10.17265 / 2328-7144 / 2015.1112 .002$

Kohpaiboon, A. (2003). Foreign Trade Regime and FDI-Growth Nexus: A Case Study of Thailand.

Kotrajaras, P., Tubtimtong, B., \& Wiboonchutikula, P. (2011). Does FDI enhance Economic Growth? New Evidence from East Asia. ASEAN Economic Bulletin, 28(2), 183-202. doi:10.1355/a

Li, X., \& Liu, X. (2005). Foreign Direct Investment and Economic Growth: An Increasingly Endogenous Relationship. World Development, 33(3), 393407. Doi: 10.1016/j.worlddev.2004.11.00.

Merican, Y. (2009). Foreign Direct Investment and Growth in ASEAN-4 Nations. International Journal of Business and Management, 4(5), 46-62. 
Moudatsou, A., \& Kyrkilis, D. (2011). FDI and Economic Growth: Causality for the EU and ASEAN. Journal of Economic Integration, 26(3), 554-577.

Narines, S. (2008). Forty Years of ASEAN: A Historical Review. The Pacific Review, 21(4), 411-429.

Olofsdotter, K. (1998). Foreign Direct Investment, Country capabilities and Economic Growth.

Pradhan, R. P. (2009). The FDI-Led-Growth hypothesis in ASEAN-5 countries: Evidence from Co-integrated Panel Analysis. International Journal of Business and Management, 4(12), 153-164.

$\mathrm{Vu}, \mathrm{T}$. B. (2008). Foreign Direct Investment and Endogenous Growth in Vietnam. Applied Economics, 40(9), 1165-1173. Doi: 10.1080/00036840600749433.

Zhang, K. H. (2001). Does Foreign Direct Investment promote Economic Growth? Evidence from East Asia and Latin America. Contemporary Economic Policy, 19(2), 175-185. 